\title{
Rural Entrepreneurship and Enterprise Development:A Way Out to Increasing Landlessness and Sole Dependence on Farming in the Rural Economy
}

\author{
Abebe kebie Tewabe Gashaw \\ Department of Management, Bahir Dar University, Ethiopia, p.o.box. 79
}

\begin{abstract}
The theme of this research is on rural entrepreneurship and enterprise development as a way out to the increasing sole dependence of rural community in farming in the face of many problems basically land scarcity/landlessness, highly rain fed agriculture where the community should wait for god to bring the rain. If the rain comes on time it is ok, if not, one can imagine all kind of repercussion for a household which entirely depends on farming for a livening. In addition it would be naïve to think in Ethiopia farming will sufficiently feed and transform this growing population Therefore, it is crucial to think of other economic sectors mainly rural entrepreneurship and enterprise development. This research focused on factors that affect rural entrepreneurship and enterprise development of rural communities in regard with the Asset-access-activitiesoutcome framework of rural entrepreneurship and enterprise development model. A survey was undertaken at household level with sample elements (households) which were taken through cluster probability/random sampling method. The data that were obtained from the sample households was analyzed quantitatively through binary nominal logistic regression model since the target variable is defined as a categorical variable which is a dichotomy. The odds ratio method was used to predict the presence or absence of a characteristic or outcome (adoption of rural enterprise development by a household in this case) based on values of a set of predictor variables.
\end{abstract}

Keywords: rural entrepreneurship, enterprise development

\section{Introduction}

\section{Background and Problem}

Despite development initiatives and efforts in our globe, yet millions are still struggling to meet their livelihoods at acceptable standards. Even in countries that experienced economic growth, inequality and exclusion have grown sharply and chronic poverty and livelihood insecurity increased. Particularly in Africa Livelihoods insecurity in rural areas is subject to many complex causes, including climate Change, environmental degradation, conflict, a huge increase in population size, etc.

Particularly in eastern Africa the breadth and depth of poverty and vulnerability are increasing as a consequence of increased exposure to natural and human induced shocks and stresses and hence increasingly large number of households live in the face of insecurity. The situation in Ethiopia is not different if it is not worse at all.

Ethiopia's economy is based on agriculture, accounting for almost $45 \%$ of GDP, and $85 \%$ of total employment (MOFED, 2003). The agricultural sector suffers from frequent drought and poor cultivation practices. What makes the situation more difficult is that agriculture is highly dependant on natural rain fall which is too seasonal so that the community has to wait for 'god' to bring the rainy season so that they start cultivation. If the rain comes on time that is all right but if the rain fails to come one can imagine all kinds of repercussion it can create on the livelihood security of the community. Even in good times when the rain comes on time the amount of livelihood security is not as such due to a small amount of land owned by the people and consequently small amount of production.

Ethiopia is experiencing a huge population growth. The country's population has increased frome19.6 million in 1950 to 70.7 million in 2003, increase by 51.5 million with in 53 years. If the current rate of population growth which is $2.7 \%$ continuous the population will amount to 117.6 million in 2025,21 years away and 173.3 million in 2050 (CSA, 2007). Hence Ethiopia will be one of the ten populated nations in the planet probably with a poor economic condition. Even if there are literatures and arguments in favor of large population size which consider it as resource (Boserup,1965) evidence is skewed to the fact that unprecedented population growth will lead to livelihood insecurity (Malthus,). In addition it would be too naive to assume that farming alone will feed this growing population.

Particularly household access to agricultural land is becoming a growing problem due to population growth; average holding is decreasing as peasants subdivide their plots to accommodate newly married son and daughter's .In addition to diminishing of land holdings landless households are prevalent in today's rural Ethiopia (Desalegn,1999).

The tradition is that a household gives piece of land when his children are grown and get married and need 
to be a separate self help household. This decision makes both families worse of but they do not have any better alternative. All members of a given household cultivate a piece of land which can be effectively cultivated by only some member of the household. In economic terms what is called marginal productivity of the additional labor is zero or negative. In addition in a given calendar year the busy time of the rural community is the rainy season. At other time of the year farmers including the member of the household are idle. This is what economists call seasonal unemployment.

In a nut shell farming as a means of livelihood is intertwined with multiple problems such as sole dependent of on farming, rain fed agriculture which is highly dependent on nature, high population growth and hence acute shortage of land which is the prime means of production for farming and landlessness, etc. Hence, it is no more sustainable economic activity alone. Rural entrepreneurship and enterprise development is an important economic strategy to break the poverty trap in which the rural community is in.

Of course, literature suggests different development strategies for such a scenario. Some of strategies include Intensification (an attempt to increase productivity in the existing land under cultivation), extensification, (an attempt to raise agricultural productivity in the given small land or bringing new land in to cultivation if at all it exists), rural entrepreneurship and enterprise development, resettlement are few among others. Intensification or extensification corresponds attaches a continuous importance on agriculture mainly farming where land is still the basic resource which is not the theme of this research.

The theme of this research is on rural entrepreneurship and enterprise development , the process by which rural households construct an increasing diverse portfolio of activities, assets social support capabilities in order to survive and to improve their standards of living and improve household security (Ellis, 1998). After all there is no sufficient political, economical reason that children from a rural farming household could remain farms in the face of acute shortage of land and an agricultural system which is totally surrendered to nature which is rain feed. Therefore, the prime aim of the research is to asses the key determinant of household enterprise development, in order to contribute to the theoretical and policy debate in entrepreneurship development and come up with policy recommendations that promote rural entrepreneurship and enterprise development.

\section{Objective of the Study}

The general objective of the study is to assess factors that affect rural entrepreneurship and enterprise development of rural communities which serve as incentives or disincentive in regard with the Asset-accessactivities-outcome framework of rural entrepreneurship and enterprise development model. Specifically the research: Assesses the effect of household asset/capital base on rural entrepreneurship and enterprise development

\section{Relevance /significance}

This research is significant practically and theoretically. When it comes to the practical relevance, it plays a pivotal role in policy making particularly rural policy making. Though lately the Ethiopian government has recognized the importance of the non farming sector in the economy and hence policies that encourage rural entrepreneurship and enterprise development are pivotal and hence they should be addressed .In addition the research contributes to the current knowledge gap and policy debate on how to foster rural entrepreneurship and enterprise development. Hence the research output contributes to policy making in addition to its theoretical relevance.

\section{Literature Review \\ Basics of Rural Entrepreneurship and Enterprise Development Entrepreneurship}

The entrepreneurship concept, what it means and where it comes from, is the foundation for policies promoting entrepreneurship and the key to understanding the role of entrepreneurship in development.

\section{What, who and why?}

Defining entrepreneurship is not an easy task. There are almost as many definitions of entrepreneurship as there are scholar books on the subjects (Byrd W.A., 1987, p. 3). To some, entrepreneurship means primarily innovation, to others it means risk-taking, to others a market stabilizing force and to others still it means starting, owning and managing a small business. Accordingly, the entrepreneur is then viewed as a person who either creates new combinations of production factors such as new methods of production, new products, new markets, finds new sources of supply and new organizational forms; or as a person who is willing to take risks; or a person who, by exploiting market opportunities, eliminates disequilibrium between aggregate supply and aggregate demand, or as one who owns and operates a business (Tyson, Petrin, Rogers, 1994, p. 2-3).

To choose the definition of entrepreneurship most appropriate for the rural area context, it is important to bear in mind the entrepreneurial skills that will be needed to improve the quality of life for individuals, families 
and communities and to sustain a healthy economy and environment. Taking this into consideration, we will find that each of the traditional definitions has its own weakness (Tyson, Petrin, Rogers, 1994, p. 4). The first definition leaves little room for innovations that are not on the technological or organizational cutting edge, such as, adaptation of older technologies to a developing-country context, or entering into export markets already tapped by other firms. Defining entrepreneurship as risk-taking neglects other major elements of what we usually think of as entrepreneurship, such as a well-developed ability to recognize unexploited market opportunities. Entrepreneurship as a stabilizing force limits entrepreneurship to reading markets disequilibria, while entrepreneurship defined as owning and operating a business, denies the possibility of entrepreneurial behavior by non-owners, employees and managers who have no equity stake in the business. Therefore, the most appropriate definition of entrepreneurship that would fit into the rural development context, argued here, is the broader one, the one which defines entrepreneurship as: "a force that mobilizes other resources to meet unmet market demand", "the ability to create and build something from practically nothing", "the process of creating value by pulling together a unique package of resources to exploit an opportunity". It combines definitions of entrepreneurship by Jones and Sakong, 1980; Timmons, 1989; Stevenson, et al., 1985.

Entrepreneurship so defined, pertains to any new organization of productive factors and not exclusively to innovations that are on the technological or organizational cutting edge, it pertains to entrepreneurial activities both within and outside the organization. Entrepreneurship need not involve anything new from a global or even national perspective, but rather the adoption of new forms of business organizations, new technologies and new enterprises producing goods not previously available at a location (Petrin, 1991). This is why entrepreneurship is considered to be a prime mover in development and why nations, regions and communities that actively promote entrepreneurship development, demonstrate much higher growth rates and consequently higher levels of development than nations, regions and communities whose institutions, politics and culture hinder entrepreneurship.

An entrepreneurial economy, whether on the national, regional or community level, differs significantly from a non-entrepreneurial economy in many respects, not only by its economic structure and its economic vigorousness, but also by the social vitality and quality of life which it offers with a consequent attractiveness to people. Economic structure is very dynamic and extremely competitive due to the rapid creation of new firms and the exit of 'old' stagnant and declining firms. It is populated with rapidly growing firms, gazelles as they are called in the literature of entrepreneurship. Gazelles are the key to economic development. As described by Twaalfhoven and Indivers (1993, pp. 3-4), they are run by dynamic entrepreneurs, who manage and lead their companies not only to remain in the business but to expand it. Dynamic entrepreneurs look for growth, they do not have only a vision but are also capable of making it happen. They think and act globally, look for expansion, rely on external resources, seek professional advice or they work with professional teams. They challenge competitors instead of avoiding them and take and share risks in a way that leads to success. In this way economic vitality of a country largely depends on the overall level of entrepreneurial capacity, i.e., on its ability to create rapidly growing companies, gazelles. Equally important is the speed by which new small companies are created. These phenomena explain why countries, regions and communities with a similar number of large and small firms show a completely different economic vitality.

As evidence suggests, it is false to assume that socially and economically depressed areas will transform into fast growing areas by injection of external investment funds and external expertise. Without entrepreneurial capabilities which are well developed or potentially available, external funds will be wasted on projects that will not provide long term economic growth. Consequently instead of becoming more and more integrated into other economically and socially rich areas, such areas will become increasingly isolated, depopulated, poorer and therefore less and less capable of attracting people who, given other available resources, would make an impact from a development standpoint.

Entrepreneurial, orientation to rural development, contrary to development based on bringing in human capital and investment from outside, is based on stimulating local entrepreneurial talent and subsequent growth of indigenous companies. This in turn would create jobs and add economic value to a region and community and at the same time keep scarce resources within the community. To accelerate economic development in rural areas, it is necessary to increase the supply of entrepreneurs, thus building up the critical mass of first generation entrepreneurs (Petrin, 1992), who will take risks and engage in the uncertainties of a new venture creation, create something from practically nothing and create values by pulling together a unique package of resources to exploit an opportunity. By their example they will stimulate an autonomous entrepreneurial process, as well as a dynamic entrepreneurship, thereby ensuring continuous rural development.

It is important to stress that rural entrepreneurship in its substance does not differ from entrepreneurship in urban areas. Entrepreneurship in rural areas is finding a unique blend of resources, either inside or outside of agriculture. This can be achieved by widening the base of a farm business to include all the non-agricultural uses that available resources can be put to or through any major changes in land use or level of production other than those related solely to agriculture. Thus, a rural entrepreneur is someone who is prepared to stay in the rural area 
and contribute to the creation of local wealth. To some degree, however, the economic goals of an entrepreneur and the social goals of rural development are more strongly interlinked than in urban areas. For this reason entrepreneurship in rural areas is usually community based, has strong extended family linkages and a relatively large impact on a rural community.

\section{Rural entrepreneurship}

Many examples of successful rural entrepreneurship can already be found in literature. Diversification into nonagricultural uses of available resources such as catering for tourists, blacksmithing, carpentry, spinning, etc. as well as diversification into activities other than those solely related to agricultural usage, for example, the use of resources other than land such as water, woodlands, buildings, available skills and local features, all fit into rural entrepreneurship. The entrepreneurial combinations of these resources are, for example: tourism, sport and recreation facilities, professional and technical training, retailing and wholesaling, industrial applications (engineering, crafts), servicing (consultancy), value added (products from meat, milk, wood, etc.) and the possibility of off-farm work. Equally entrepreneurial, are new uses of land that enable a reduction in the intensity of agricultural production, for example, organic production. Dynamic rural entrepreneurs can also be found. They are expanding their activities and markets and they find new markets for their products and services beyond the local boundaries.

To leave general examples of rural entrepreneurship behind, let us look at the real cases. Here only a few will be mentioned, all illustrating entrepreneurial initiatives, individuals and local communities from Great Britain. The names of entrepreneurs we have chosen to present here are not globally known but are no less important because of that. They are very well known to the communities to which they belong and their initiatives are highly appreciated by the community members. One of them is Graham-Probin (Johnstone et al., 1990, p. 9), owner of a 110 acre farm in Malpas, Cheshire, England. By converting a two-storey building into four workshop units, he created employment opportunities within the community. Another one is John Anderson from Kirkwhelpington, who created employment opportunities in the local area by restoring traditional stables into business premises and renting them out to a blacksmith who shoes horses and does light engineering work for farmers (Johnstone et al., 1990, p. 9-10). Another is the McNamara family from Canaston Bridge. They responded to the dairy quotas imposed by the Government by diversification of their land for non-agricultural usage. The family converted 80 acres of land into an adventure and leisure complex. After three years of investment, amounting to $£ 800000$, the adventure and leisure facilities were opened in 1987, boasting a range of attractions entirely unconnected with agriculture, such as: a bobsleigh run, a miniature railway, a pitch and putt golf course, a natural history centre, go-kart tracks, assault courses, a restaurant and various shops (Johnstone et al., 1990, p. 18). This entrepreneurial venture is an example of a straightforward entrepreneurship and not so much an example of on-farm diversification. It is an example of how seeing and seizing the opportunity is vital ingredients of entrepreneurial success.

Although agriculture today still provides income to rural communities, rural development is increasingly linked to enterprise development. Since national economies are more and more globalized and competition is intensifying at an unprecedented pace, affecting not only industry but any economic activity including agriculture, it is not surprising that rural entrepreneurship is gaining in its importance as a force of economic change that must take place if many rural communities are to survive. However, entrepreneurship demands an enabling environment in order to flourish.

\section{Analytical /Conceptual Framework/Modeling}

The prime concern of this reserch is on rural enterprenurship and enterprise development. There are different models , concept and frameworks which try to explian the prccess of rural enterprenursip and enterprise development. Among others the assets-accsses- activities frame work is the dominant frame work used by different scholars and development agencies concerned in rural enterprenurship and enterprise development. This reserch capitalizes on this model/frame work.

The asset base of a given household which is considered as a determinant factor in affecting the intensity of rural entrepreneurship and enterprise development in the household is made up of the following components: Human capital ('the skills, knowledge, ability to labor and good health important to the ability to pursue different livelihood strategies), natural capital (the natural resource stocks from which resource flow useful for livelihoods are derived), physical capital (the basic infrastructure ... and the production equipment and means which enable people to pursue their livelihoods), financial capital (the financial resources ... whether savings, supplies of credit or regular remittances or pensions which provide [people] with different of rural entrepreneurship and enterprise development in the household, and Social capital (the social resources ... upon which people draw in pursuit of livelihoods (Carney, 1998: 7).

Rural entrepreneurship and enterprise development is affected by large number of contextual social, economic, and policy issues in addition to the asset base that households have and the socio economic 
characteristics of a household. This is what is referred as mediating process. Readon and Vosti (1998) call these factors in general conditioning factors.

In a nut shell mandating factors what so ever terminology is used to explain them it refers to factors such as polices, institutions and social relations. An institution which may be formal or informal refers to regular practices or patterns of behavior structured by rules and norms and play a pivotal role in diversification of rural livelihoods. Mediating factors are critical elements of diversification schemes. It is not only the amount of money that one has that determines the amount and sector to which one invests but also the investment policy which is equally important. By the same token it is not only the asset portfolio and household socio economic characteristics that determine rural entrepreneurship and enterprise development endeavors but also mediating factors play a critical role.

In this research mediating factors refers to Policies and Institutions. Rural entrepreneurship and enterprise development is not just only affected by capital assets and socio economic conditions of a household. They are also determined by the environment of structures and processes. Structures are the public and private sector organizations that set and implement policy and legislation, deliver services, and purchase, trade, and perform all manner of other functions that affect livelihoods (Lewis,p,A2002). Processes in the other hand embrace the laws, regulations, policies, operational arrangements, agreements, societal norms, and practices that, in turn, determine the way in which structure operate (Lewis,p,A2002).

Institutions, policies and processes mediate rural household's access to and control over resources (DFID, 1999). Institutions are the social cement which link stakeholders to access to capital of different kinds to the means of exercising power and so define the gateways through which they pass on the route to positive or negative livelihood adaptation (Scoones, 1998). Within this broader context, these different categories of households belong to and draw support from a multiplicity of formal and informal local institutions.

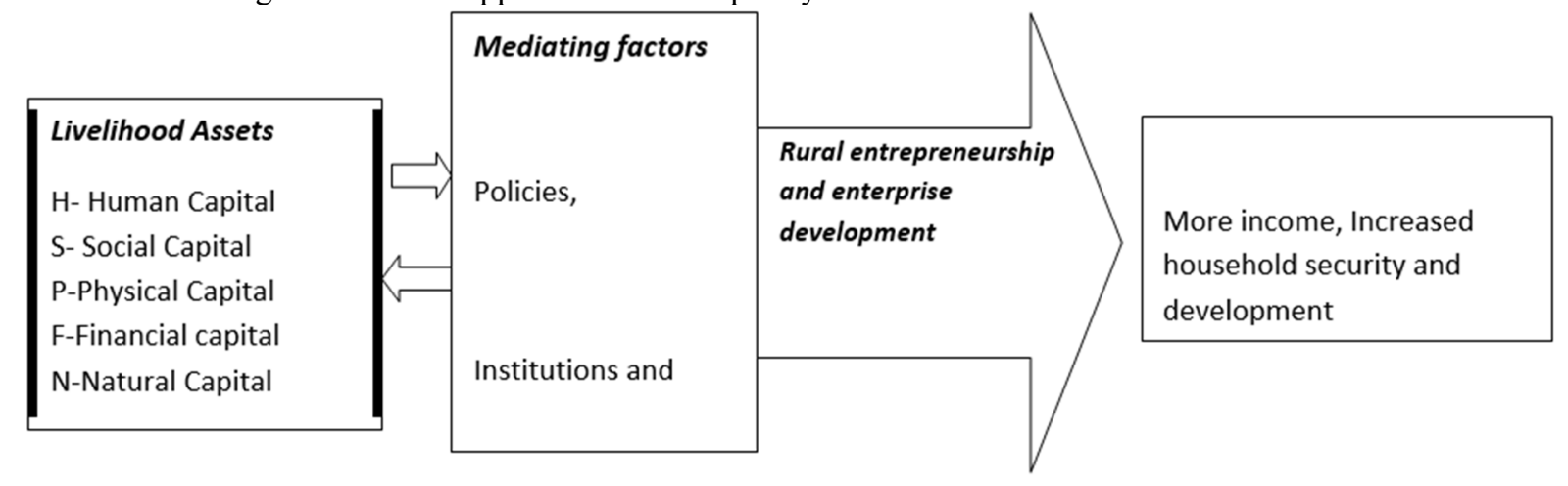

Source:

Adapted and modified from Lovendal et al., (2004), Asset-access-activities-outcome framework

\section{Research Methodology}

\section{The Research Design.}

Two of the most important design issues that affect the rigor of a particular research namely the agency structure debate and the qualitative and quantitative design are elaborated in the following few paragraphs as far as this research project is concerned.

The structure agency problem is about the unit of data collection and data analysis for the study which is called level of analysis. There are two level of analysis: micro level analysis (individual or actor centered analysis) and macro level (system or structural analysis). In the research methodology literature this concept is called the structure agency problem (Mcanulla,S 2002). Fundamentally the structure agency debate concerns the issue to what extent individuals and groups as actors have the ability to shape their destiny (shape social phenomena) against the extent to which group and individuals lives are structured in ways out of our control, the degree to which our fate is determined by external factors. In line with this agency refers to individual or group abilities to affect their environment. Structure on the other hand refers to context, to the material conditions which define the range of actions available to actors (Mcanulla,S 2002).

As far as this research is concerned the central research theme is about factors that affect rural entrepreneurship and enterprise development of the rural community. These factors will fall in the structure agency dichotomy. At one hand are the micro level issues rural households them selves including their household level factors/ variables that affect entrepreneurship and enterprise development effort of the household. This is what social researchers call agency. At the other hand is what is called structure or system which refers to institutional rural macro issues that affect rural entrepreneurship and enterprise development. This research gives particular attention to agency factors.

When it comes to the qualitative and quantitative discourse most often than not agency factors are best 
studied and uncovered using quantitative approach hence the study subscribed to quantitative approach.

\section{Sampling Design}

The research used cluster sampling. The household is the basic economic decision making unit in rural society. There for households is the basic unit of analysis for the study.

The target populations of the study are the households in the 32 kebeles of the woreda. First from the study woreda 5 (five) kebeles were selected which serve the purpose of clusters. Next from each cluster, Kebele in this case, a representative amount of households were selected through random sampling. In this case the list of household inhabitants at the Kebele level had served as a sampling frame from which the samples required were drawn randomly. From the 5 kebeles a total of 200 households were selected for the case of survey.

Population of the study woreda by Kebele (2005) and kebeles included in the sample is shown below.

\begin{tabular}{|l|l|l|l|}
\hline Kebeles & Total population & Kebele & Total population \\
\hline Abaraje Giorgis & 4791 & Oura Kidanmret & 3739 \\
\hline Alehaye So & 5586 & Robet Bata* & 8900 \\
\hline Betmariam & 3216 & Seba Tamet* & 7464 \\
\hline Chenta Sos & 8007 & Seklate & 2876 \\
\hline Dehena Mes & 7613 & Tenea Che & 6674 \\
\hline Derebanta & 2845 & Wegalesa * & 4568 \\
\hline Ferase Weg & 6547 & Wejerat & 5526 \\
\hline Geneb Sose & 6702 & Wenedata * & 3935 \\
\hline Gonebat Ab & 5895 & Wenejta & 10607 \\
\hline Kefelo Maq & Weramet & 9207 \\
\hline Kenebaba & 5848 & Wereke Mel & 3103 \\
\hline Laguna Abu & 12355 & Werube Kol & 7824 \\
\hline Lata Amba & 2556 & Yebabe Eyesus & 5074 \\
\hline Lejme & 9363 & Yegind Lomi & 8432 \\
\hline Maje Daber & 7398 & Yegode Ten & 3618 \\
\hline Meshenety & 5167 & Yegoma Huletu & 9484 \\
\hline & 3136 & Yeloma Yeg & 5670 \\
\hline Yemeesign & & Yisalana Dirdira & 8920 \\
\hline Yemeshte D & 4279 & Zenzelma & 8636 \\
\hline
\end{tabular}

Table1. Population of the study woreda by Kebele (2005) Source: Amhara region food security, disaster and preparedness commission

*kebeles selected for the sample from which the households were selected

\section{Data Collection Methods, Instruments and Procedures}

For the cross sectional survey questionnaires were developed and administered at household level since the unit of data collection and analysis is at household level. The questionnaires were tested for reliability and validity in advance. To this end at most effort were made to solicit ideas about the questionnaires from professionals who have done a research on a similar issue and are rich with the literature in the area. In addition, the questionnaires were pre tested in a pilot before it was administered at full scale. Data collectors and enumerators were trained on data collection basics and collected the data with a strong supervision, follow up, and support from the researchers.

\section{Variable Specification}

Many factors come in to play and determine the choice of a particular household to engage in rural entrepreneurship and enterprise development endeavors. The dependent and independent variables considered for the sake of this study are indicated in the table below in terms of the name of the variables and their roles (as to wither they are a predictor or target. 


\begin{tabular}{|l|l|}
\hline Variable & $\begin{array}{l}\text { Role of the variable in the } \\
\text { model }\end{array}$ \\
\hline Family size & input(predictor) \\
\hline Sex composition of household members & input(predictor) \\
\hline Health Status of household members & input(predictor) \\
\hline Gender of household head & input(predictor) \\
\hline Education level of household head & input(predictor) \\
\hline Land size held by HHs & input(predictor) \\
\hline Farmer's perception of soil fertility status of land owned & input(predictor) \\
\hline Farming Livestock holding & input(predictor) \\
\hline Non farming livestock holding & input(predictor) \\
\hline Member of rural finance source such as ikub ${ }^{1}$ & input(predictor) \\
\hline Credit access (formal or informal) & input(predictor) \\
\hline $\begin{array}{l}\text { Membership to local institutions such as farmers associations, kinships, } \\
\text { marriage with local people etc }\end{array}$ & input(predictor) \\
\hline Access to mass media radio television, news paper or any & input(predictor) \\
\hline Access to communication such as telephone postal services or any & input(predictor) \\
\hline Livelihood of the house hold & Target \\
\hline
\end{tabular}

\section{Data Analysis and Discussion}

The Model and Its Relevance

Data for this study is cross-sectional data obtained from 200 respondents from five rural kebeles in Bahir Dar zuria woreda. All the Kebeles and respondents were selected using probability sampling procedures. For analysis purpose the conceptual framework of sustainable livelihoods which is indicated below was used as a basic reference as discussed in the literature part of this study.

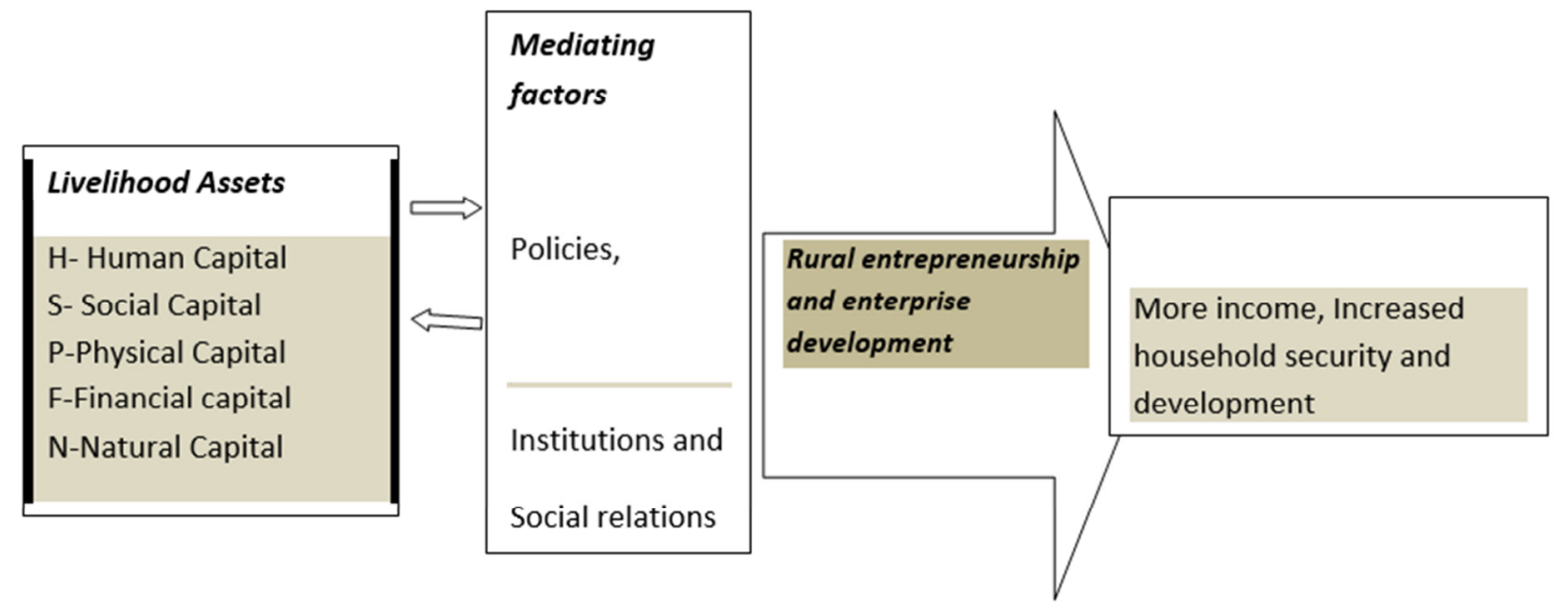

Source: Adapted and modified from Lovendal et al., (2004), Asset-access-activities-outcome framework

The livelihood framework theoretical framework applied for determining the effects of the factors influencing participation in rural entrepreneurship and enterprise development has its roots in the threshold theory of decision making. To involve in rural enterprise development or not is a decision of the household hence the threshold theory was found to be more appropriate for the study. In Ethiopian setting the household head in most cases is the one who decided in what livelihood activities members of the family should engage in. In this theory, a reaction occurs only after the strength of the stimuli increases beyond the individual's reaction threshold (Hill and Kau, 1973). Households' decision to participate in rural entrepreneurship and enterprise development is therefore dichotomous variable between two mutually exclusive alternatives: either to involve in rural enterprise development and rural entrepreneurship or not to participate. The probability that an individual makes a particular choice is influenced by a vector of explanatory variables which are called independent variables. Particularly in this study the decision to involve in rural enterprise development or not depends on many explanatory variables which are referred as independent variables in the study which includes Family size ,Mean age of household members, Sex composition of household members, Health Status of household

\footnotetext{
${ }^{1}$ Ikub: refers to an informal finance institutions where finite number of members contribute a fixed amount of money where the money polled is given to a member selected by lottery where by the process continues until all members get the chance. One all members get the chance the ikub may continue or not depending the interest of the members
} 
members, to mention few among others. . Thus, a decision to participate in rural entrepreneurship and enterprise development will occur only when the combined effect of the explanatory variables (Xi' $\beta$ ) reaches a certain unobservable critical value $Y i^{*}$. Therefore

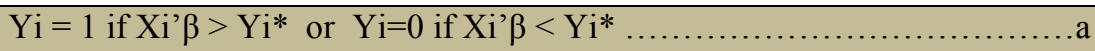

Where $Y i^{*}$ is a latent variable and represent the unobserved level of participation in rural entrepreneurship and enterprise development endeavors. Consequently by the application of the logic of probability theory, the probability that a given individual participates in rural entrepreneurship and enterprise development is given by:

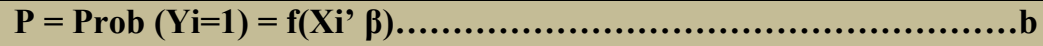

Consequently the probability that a given individual does not participate in rural entrepreneurship and enterprise development is given by:

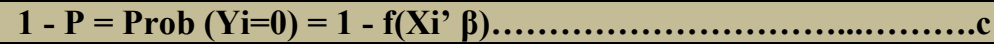

Since the dependent variable in this research is a categorical binary where in an individual household either decides to participates in rural entrepreneurship or no to participate in rural entrepreneurship and enterprise development, binary logit regression was found to be appropriate to be employed in the study to estimate the probability of participation of a household in rural entrepreneurship and enterprise development. The logit model specified for the study is stated as follows.

$\mathrm{L}=\mathrm{Log}(\mathrm{pi} / 1-\mathrm{pi})=\beta \mathrm{o}+\sum \beta \mathrm{iXi}+\mathrm{Ui}$

Where: $\mathrm{Pi}=$ the probability that an individual will participate in rural entrepreneurship and rural enterprise development

$\beta \mathrm{o}=$ the constant

$\beta \mathrm{i}=\mathrm{a}$ vector of unknown coefficients of the determinants of participation in rural entrepreneurship and enterprise development for a household under consideration

$\mathrm{X}=\mathrm{a}$ vector of independent variables that determine participation in rural enterprise development and includes the dependent variables of the study such as Family size ,Mean age of household members, Sex composition of household members, Health Status of household members, to mention few among others .

$\mathrm{Ui}=$ is the stochastic error term and

$\mathrm{i}=1,2,3 \ldots N(200)$ observations.

To give meaning for the results of the regression two important indicators are applied .In this regard the $\mathrm{Z}$ statistic is used to test the significance of the individual parameters under consideration. The fitness of the model is tested via the likelihood ratio test (LRT). The variables used in the model and their role (dependent and independent) are presented in Table below. 


\begin{tabular}{|l|l|}
\hline Variable & $\begin{array}{l}\text { Role of the variable in the } \\
\text { model }\end{array}$ \\
\hline Family size & input(predictor) \\
\hline Sex composition of household members & input(predictor) \\
\hline Health Status of household members & input(predictor) \\
\hline Gender of household head & input(predictor) \\
\hline Education level of household head & input(predictor) \\
\hline Land size held by HHs & input(predictor) \\
\hline Farmer's perception of soil fertility status of land owned & input(predictor) \\
\hline Farming Livestock holding & input(predictor) \\
\hline Non farming livestock holding & input(predictor) \\
\hline Member of rural finance source such as ikub & input(predictor) \\
\hline Credit access (formal or informal) & input(predictor) \\
\hline $\begin{array}{l}\text { Membership to local institutions such as farmers associations, kinships, } \\
\text { marriage with local people etc }\end{array}$ & input(predictor) \\
\hline Access to mass media radio television, news paper or any & input(predictor) \\
\hline Access to communication such as telephone postal services or any & input(predictor) \\
\hline Livelihood of the house hold & Target \\
\hline
\end{tabular}

\section{Result and Discussion}

Given that the target variable was defined as a categorical binary (a decision of a particular house hold to participate or not in rural entrepreneurship and enterprise development) which is affected by the predictor variables which include family size, sex composition of the house hold, health status of the household members, gender of house hold head etc. Binary Logistic Regression was found to be appropriate to see the effect of the predictor variables on the target variable. The following is the spss result for such regression given the above model and variable specifications.

\begin{tabular}{|l|l|l|l|}
\hline & Coefficient & Odds Ratio & $\mathbf{P}>\mathbf{Z}$ \\
\hline Constant & 5.153313 & 5.153313 & 0.003 \\
\hline Family size & $-2.554634^{* * *}$ & $0.045731^{* * *}$ & 0.000 \\
\hline Sex composition of household members & $-0.0240921^{*}$ & $0.9553421^{*}$ & 0.080 \\
\hline Health Status of household members & $-1.73138^{*}$ & $0.17803^{*}$ & 0.0921 \\
\hline Gender of household head & -0.4144231 & 0.5881411 & 0.655 \\
\hline Education level of household head & -0.6503705 & 0.4362143 & 0.489 \\
\hline Land size held by HHs & -0.5154327 & 0.58613110 & 0.655 \\
\hline Farmer's perception of soil fertility status of land owned & -0.6504804 & 0.4161042 & 0.469 \\
\hline Farming Livestock holding & $0.1136669^{*}$ & $1.121685^{*}$ & 0.074 \\
\hline Non farming livestock holding & $1.879508^{*}$ & $6.44017^{*}$ & 0.0453 \\
\hline Member of rural finance source such as ikub ${ }^{2}$ & 0.0071227 & 1.006187 & 0.7241 \\
\hline Credit access (formal or informal) & $1.493811^{* *}$ & $4.757511^{* *}$ & 0.007 \\
\hline $\begin{array}{l}\text { Membership to local institutions such as farmers associations, kinships, }, \\
\text { marriage with local people etc }\end{array}$ & 0.03476178 & 1.015087 & 0.668 \\
\hline Access to mass media radio television, news paper or any & 0.0151118 & 1.00617 & 0.723 \\
\hline Access to communication such as telephone postal services or any & $1.533821^{* *}$ & $4.757511^{* *}$ & 0.008 \\
\hline
\end{tabular}

\section{Log Likelihood $=-49.283637 \mathrm{LR}$ Chi $(12)=59.48$}

\section{Prob $>$ Chi2 $=0.0000$ Pseudo $R 2=0.3764$}

The above table shows the binary logit regression results of the study. Many interpretations are possible from the above regression result. The result portrays the effect each of the variables (independent variables) on the dependent variable (the decision of a household to participate or not to participate in rural entrepreneurship and enterprise development. Family size, sex composition of household members, health status of household members, farming livestock, non farming livestock, credit availability and access to communication were found

\footnotetext{
${ }^{1}$ Ikub: refers to an informal finance institutions where finite number of members contribute a fixed amount of money where the money polled is given to a member selected by lottery where by the process continues until all members get the chance. One all members get the chance the ikub may continue or not depending the interest of the members

${ }^{2}$ Ikub: refers to an informal finance institutions where finite number of members contribute a fixed amount of money where the money polled is given to a member selected by lottery where by the process continues until all members get the chance. One all members get the chance the ikub may continue or not depending the interest of the members
} 
to affect the decision of the household to involve in rural enterprise development at a significant level. Hence government polices and interventions should focus in these variables as far as the result of this study is concerned.

Family size which was measured as the number of productive workforce in a house hold has a positively and statistically significantly affected the decision of the household to engage in rural entrepreneurship and enterprise development activities. This may be due to the fact that when there is surplus labor to cultivate the farming activities of the house hold the surplus labor will specialize on non farming activities to increase income and livelihood sustainability of the household.

Health status of the house hold which was defined as the number of the permanently health and capable number of house hold members and sex composition of the household which was defined as the number of male and female members of the family was also found to affect the target variable at a significant level.

Farming and non farming livestock of the household which is measured in the number and type of livestock owned by the family is also found to have a positive relationship on the decision of the household to participate in entrepreneurial activities. For example, a family having different livestock can generate income other than the main farming activity by selling milk and milk products, animals for meat, etc.

Credit availability which is defined in the number of financial institutions which can give credits to the rural community is another factor having a significant impact on the dependent variable under consideration. If rural people have access to financial credits, they can create additional income generating activities thereby improving their lives.

Access to communication which is measured in the available communication media such as telephone and postal services is also found to have a much positive impact on the household decision to engage in entrepreneurship and enterprise development activities. With better communication technologies the rural community can create markets for its products and services can learn new ways of doing things, and the like.

\section{Conclusion and Recommendation Conclusions}

Using a cross sectional survey from five kebeles in Bahir Dar Zuria woreda, this study tried to analyze the factors which affect the decision of a household to participate or not to participate in entrepreneurial and enterprise development activities.

As it was evidenced from the binary logit regression given previously, among others, family size, sex composition of household members, health status of household members, farming and non farming livestock, credit availability and access to communication were found to affect the decision of the household to involve in rural enterprise development at a significant level.

Where the size, sex composition and health status of the members of the family is better, a household will have more time and more human capital to engage in different entrepreneurial activities. For example some of the family members can work the normal agricultural work and some others will be engaged in other activities such as fattening, poultry, milk production, and the like.

With the same token, the availability of farming and non farming livestock is one of the determining factors for the dependent variable under consideration, the decision of the household to participate or not to participate in entrepreneurial activities because it can use its livestock to generate additional income for the family.

Last but not least is the availability of financial credits and the access to different communication media which was found to have a significant impact on the household decision. If there are different financial institutions which provide credit services to the rural community, there is a higher chance of starting income generating activities other than the main agricultural work. The same is true for the access of different communication media which can help the rural community get markets for its product and services, learn new methods of doing things in a better and efficient way.

\section{Recommendations}

As the findings of this study revealed, the decision of a household to participate in rural entrepreneurship and enterprise development activities is mainly affected by the size and sex composition of the family, health status, availability of farming and non farming livestock, availability of financial credits and access of the rural community to different communication technologies. Hence, our recommendations will be mainly focusing on these issues.

As family size and sex composition are found to be a determining factor for rural entrepreneurship and enterprise development, different awareness creation mechanisms must be devised for the rural community which can help them use their family members to create different income generating activities.

Health status is also a significant factor for rural entrepreneurial activities and different health centers must be established which can improve the health status of the rural community.

It is known that most of the people in the rural areas have many farming and non farming livestock. The 
problem is they are not using their livestock for additional income generating activities other than the common agricultural work. Hence, attention should be given in creating awareness on the use of their livestock for generating additional income like milk processing, fattening, poultry, and the like.

Access to finance is a key for entrepreneurship and enterprise development and formal and non formal financial institutions which can give credit to the rural community must be established in addition to those currently under operation.

Finally, the rural community must have access to communication media and technology so that they can get market for their product and services and they can learn and see new ways of doing things. As a result communication technologies such as mobile networks, wireless telephones, etc must be expanded to the rural side of the country.

\section{References}

Abdulai, A. and A. Crole Rees. 2001, Determinants of income diversification amongst rural households in Southern Mali. Food Policy, 26: 437-452.

Adams, R (1994) 'Non-Farm Income and Inequality in Rural Pakistan', Journal of Development Studies, Vol. 30(1):146-167.

Admassie, A. 2007. Development policies and their implications to rural urban linkages in Ethiopia: Opportunities and challenges. In Fostering new development pathways: harnessing rural-urban linkages (RUL) to reduce poverty and improve environment in the highlands of Ethiopia, ed. Z.

Barrett, C. B, Bezuneh, M, Clay, D and Reardon, T, 2005. Heterogeneous constraints, incentives and income diversification strategies in rural Africa. Quarterly Journal of International Agriculture, 44.

Barrett, C. B., Reardon, T., Webb, P., 2001. Non-farm Income Diversification and Household Livelihood Strategies in Rural Africa: Concepts, Dynamics, and Policy Implications. Foodpolicy 26, 315-331.

Bouma,G.D and Atkinson,G,B,J(1995) A handbook of social scince reserch.acomprehensive and practical goruide for students ,nowyorksity press

Barrett, C., Reardon T. and Webb P. (2001a) Non-farm income diversification and household livelihood strategies in rural Africa: concepts, dynamics, and policy implications. Food Policy, 26, pp. 315-331.

Barrett, C., Bezuneh, M. and Aboud A. (2001b), Income diversification, poverty traps and policy shocks in Côte d'Ivoire and Kenya. Food Policy, 26, pp. 367-384.

Barrett, C.B., Bezuneh, M., Clay, C.D., and Reardon,T.(2000).Heterogeneous Constraints, incentives and income diversification strategies in rural Africa. Report to USAID/BASIS CRSP, Cornell University and Michigan State University.

Barrett, C.B., Reardon, T., and Webb, P. (2001). Non-agricultural income diversification and household livelihood strategies in rural Africa: concepts, dynamics and policy implications. Food Policy, 26(4), 315331.

Barrett, C.B., T. Reardon and P. Webb. 2001, Nonfarm income diversification and household livelihood strategies in rural Africa: concepts, dynamics and policy implications. Food Policy 26: 315 - 331.

Barrett, CB. M. Bezuneh and A. Aboud. 2001, Income diversification, poverty traps and policy shocks in Cote d'Ivoire and Kenya". Food Policy, 26: 367384.

Baumann, P., 2000. Sustainable livelihoods and political capital: Arguments and evidence from decentralization and natural resource management in India Working Paper 136. ODI, London.

Belayneh Belete, 2005. Analysis of food insecurity causes: the case of rural farm households in Metta woreda, eastern Ethiopia. An MSc Thesis Presented to the School of GraduateStudies of Alemaya University.

Berehanu Eshete, 2007. Livelihood Strategies of Smallholder Farmers and Income Poverty in draught prone areas: The case of Gena- Bosa woreda, SNNPRS. An MSc Thesis Presented to the School of Graduate Studies of Haramaya University

Bloom, D.E. and Williamson, G.W. (1998). Demographic Transitions and Economic

Bruce J.W. 2009. Land reform in Ethiopia and China: Parallels and divergences. Paper for the Inter Africa Conference on Ethiopia Land Reform, Addis Ababa

Boserup, E. 1965. The Conditions of Agricultural Growth: The Economics of Agrarian Change under Population Pressure. Chicago: Aldine. London.

Carswell, G., 2000. Livelihood diversification in southern Ethiopia IDS working paper 117

Creswell.J.W and Plano Clark,v L 2011, designing and conducting mixed methods research $2^{\text {nd }}$ ed, sage publications

Chambers, Robert and Gordon Conway. 1991. Sustainable Rural Livelihoods: Practical Concepts for the $21^{\text {st }}$ Century. IDS Discussion Paper 296: London: Institute for Development Studies.

Chambers, Robert. 1997. Whose Reality Counts: Putting the First Last. London: Intermediate Technology Publications.

Creswell, JW. Research design: qualitative, quantitative and mixed methods approach. 2nd edition. London: 
Sage. 2003

Dessalegn, R. 1999. Revisiting the land issue: Options for change. Economic Focus 2 (4). Addis Ababa: Ethiopia Economic Association.

Dixon, John, Aidan Gulliver and David Gibbon. 2001. Farming Systems and Poverty. Improving Farmers' Livelihood in a Changing World. FAO and World Bank: Rome and Washington.

Ellis Frank and Godfrey Bahiigwa. 2001. Livelihoods Poverty Reduction in Uganda Working Paper No.5. Eastwich: University of East Anglia.

Ellis, F. and H.A. Freeman. 2004. "Rural Livelihoods and Poverty Reduction Strategies in Four African Countries," Journal of Development Studies 40(4) April: 1-30.

Ellis, Frank. 1993. Peasant Economics: Farm Households and Agrarian Development. Cambridge: Cambridge University Press.

Ellis, Frank. 2000. Rural Livelihoods and Diversity in Developing Countries. Oxford: Oxford University Press.

Escobal, J. (2001). The determinants of nonfarm income diversification in rural Peru. World Development, 29(3), 497-508.

Escobal, Javier. 2001. The determinants of nonfarm income diversification in rural Peru." World Development, 29, 3: 497-508.

Evans, H.E. and Ngau, P.M., 1991, 'Rural-urban relations, household income diversification andAgricultural productivity', Development and Change, 22(3): 519-545.

FAO (2007) Rural Income Generating Activities: A Cross Country Comparison..

FDRE, 2002. Government of Ethiopia (GOE): Food Security Strategy, Addis Ababa, Ethiopia Federal Food Security Coordination Bureau (FSCB), 2004. Productive Safety Net program, environmental and social management frame work, Addis Ababa, Ethiopia

Feder, G., T. Onchan, Y. Chalamwong, and C. Hongladaron. 1988. Land policies and farm productivity in Thailand.

Ferreira, F.H.G., and Lanjouw, P. (2001). Rural non-agricultural activities and poverty in the Brazilian Northeast. World Development, 29(3), 509-528.

Ferreira, Francisco and Peter Lanjouw. 2001. "Rural non farm activities and poverty in the Brazilian North East". World Development, 29, 3: 509-528

FID, 2001. Sustainable Rural Livelihoods Guidance Sheet, London, UK

Francis, E. \& Hoddinott, J. 1993. Migration and differentiation in western Kenya: a tale of two sub-locations. Journal of Development Studies, 30 (October) (1): 115-145.

Frankenberger,T.R., Sutter, P., Amdissa,T., Alemtsehay,A., Mulugeta, T., Moges ,T.,Alemayehu, S., Bernard,T., Spangler,T., Yeshewamebrat, E., 2007.Ethiopia: The Path to Self-Reliance, Volume I:Final Report

Hirway, I. and Terhal, P., 1994, Towards Employment Guarantee In India: India And

International Experiences In Rural Public Works Programmes, New Delhi: Sage.

Gebre-Egziabiher, T. 2007. Rural urban linkage in Ethiopia: status, challenge and opportunities and future research directions. In Fostering new development pathways: harnessing rural-urban linkages (RUL) to reduce poverty and improve environment in the highlands of Ethiopia, ed. Z.

Freeman, H.A, Ellis E. \& Allison E. (2004). 'Livelihoods and Rural Poverty Reduction inKenya', Development Policy Review 22 (2): 147-171.

Gladwin, Christina, Anne Thomson, Jennifer Peterson and Andrea Anderson. 2001. "Addressing food security in Africa via multiple livelihood strategies of women farmers". Food Policy 26: 177-207.

Growth and Poverty Reduction", January 16-18, 2006, organized by the Food and Agriculture Organization, Rome.

Hussein, Karim and John Nelson. 1999. Sustainable Livelihoods and Diversification. IDS Working Paper 69. London: Institute of Development Studies.

Hussein, K., and Nelson, J., 1999. Sustainable Livelihoods and Diversification. IDS Working Paper 69. London: Institute of Development Studies.

Incentives, and Income Diversification Strategies in Rural Africa," Quarterly Journal of International Agriculture 44 (1): 37-60.

Isgut, A.E. 2004. "Non-Farm Income and Employment in Rural Honduras: Assessing the

Role of Locational Factors," Journal of Development Studies 40(3) February: 59-86.

Khan, M. A., 2007, Factors Affecting Employment Choices in Rural Northwest Pakistan. Conference on International Agricultural research for Development. University of Gottingen, Germany

Matsumoto, T., Y. Kijima, \& T. Yamano (2006) The role of local nonfarm activities

Miracles in Emerging Asia. World Bank Economic Review, 12 (3), 419-55.

MoFED, 2006, Ethiopia: Building on Progress: A Plan for Accelerated and Sustained Development to End Poverty (PASDEP) (2005/06-2009/10) Volume I

MoFED. 2002. Ethiopia: Sustainable Development and Poverty Reduction. Addis Ababa,Ethiopia. 
ODI, 2003. Understanding Livelihoods in Rural India: Diversity, Change and Exclusion, UK

Mcanulla,s(2002)stracture and agency,in D Marsh and G. Stoker(eds)thoery and methods in poletical scince,basingostoke,palgravemacmillan updated and revsed version

Pingali, Prabhu and Mark Rosegrant. 1995. "Agricultural commercialization and diversification: processes and policies". Food Policy 20, 3: 171-185.

Reardon, T, Delgado, C and Matlon, P, 1992. Determinants and effects of income diversification amongst farm households in Burkina Faso; Journal of Development Studies 28.

Reardon, T. (1997). Using Evidence of Household Income Diversification to Inform Study of the Rural Nonfarm Labor Market in Africa. World Development 25(5):735-747.

Reardon, T., C. Delgado and P. Matlon. 1992. "Determinants and effects of income diversification among farm households of Burkina Faso". The Journal of Development Studies, 28, 2: 264-296

Woldenhanna, T. and A.Oskam. 2001. "Income diversification and entry barriers: evidence from the Tigary region of Northern Ethiopia". Food Policy, 26: 351-365.

\section{ANNEX}

\section{GENERAL INFORMATION}

This questioner is meant for collecting data for the research being done by Abebe kebie and Tewabe Gashae (Lecturers at BahirDar University). The purpose of the research is purely academic . The research is funded by Bahir Dar University. The theme of the research is rural entrepreneurship and enterprise development. Your genuine response is too crucial. Since data you provided will be confidential and the principle of anonymity is adhered there will not be any social, economical or political impact on you because you have participated as respondent as in this research

Thanks in advance for your cooperation!!!

\section{Human capital (independent 1)}

\begin{tabular}{|c|c|}
\hline Variable & Measurement specification \\
\hline \# Family size & Scale, number of members of the household \\
\hline \# Mean age of household members & Scale, mean age of members of households \\
\hline \# Sex composition of household members & Scale, number of male and female in the household \\
\hline \# Health Status of household members & $\begin{array}{l}\text { Scale: member of household who are permanently ill and are } \\
\text { non productive }\end{array}$ \\
\hline \# Gender of household head & String,1:Male,2:Female \\
\hline \# Education level of household head & Scale, grade achieved by the household head \\
\hline $\begin{array}{l}\text { Mean education level of house hold } \\
\text { members }\end{array}$ & ucation grade achieved by household members \\
\hline
\end{tabular}

2. Natural capital(independent 2)

\begin{tabular}{|l|l|}
\hline Variable & Measurement specification \\
\hline Land size held by HHs & Scale, acre of land owned by the household \\
\hline \& Farmers perception of soil fertility status of land owned & String,1:fertile, 2:medium,3:poor
\end{tabular}

3. Physical capital (independent 3)

\begin{tabular}{|l|l|}
\hline Variable & Measurement specification \\
\hline Farming Livestock holding & $\begin{array}{l}\text { Scale: number of farming livestock mainly oxen owned by the } \\
\text { household }\end{array}$ \\
\hline Non farming livestock holding & Scale: number of non farming livestock owned by the household \\
\hline Mean crop output harvested & $\begin{array}{l}\text { Scale, amount of harvest by the house hold measured in local } \\
\text { standard } \\
\text { called dirb }\end{array}$ \\
\hline Input use & Scale: refers to the amount of fertilizers used in kg \\
\hline
\end{tabular}

\footnotetext{
${ }^{1}$ Drib : refers to a local standard used by farmers in the woreda to measure their out puts
} 


\section{Financial capital(independent 4)}

\begin{tabular}{|l|l|}
\hline Variable & Measurement specification \\
\hline Member of rural finance source such as ikub & String,1:yes,2:No \\
\hline Credit access (formal or informal) & String,1:yes,2:NO \\
\hline Remittance (domestic/abroad) & String1;yes,2:No \\
\hline
\end{tabular}

\section{Structural and social capital(independent 5)}

Variable

* Membership to local institutions such as farmers associations, kinships, marriage with local people etc

Measurement specification

\begin{tabular}{l}
\hline $\begin{array}{l}\text { Membership to local institutions such as farmers associations, kinships, } \\
\text { marriage with local people etc }\end{array}$ \\
$\$$ Access to mass media radio television, news paper or any \\
\hline Access to communication such as telephone postal services or any \\
$\$$ Access to motor roads
\end{tabular}

Sting, 1 :yes, 2 :No String, $1: \mathrm{yes}, 2: \mathrm{No}$ String, $1: y e s, 2:$ No String, $1: y e s, 2: \mathrm{No}$

6. Information capital (independent 6)

\section{Variable}

Measurement specification

\begin{tabular}{|c|l|}
\hline+ Access to mass media radio television, news paper or any & String, 1:yes,2:No \\
\hline \multirow{2}{|c|}{ Access to communication such as telephone postal services or any } & String,1:yes,2:No \\
\hline \multirow{3}{|c|}{ Access to motor roads } & String,1:yes,2:No \\
\hline & String,1:Non Diversified (the house hold performs farming only for a living, \\
& 2: Diversified ( a farmer performs farming plus at \\
Livelihood of the house hold & least one off farming economic activities for a living), \\
\hline
\end{tabular}

\footnotetext{
${ }^{1}$ Ikub: refers to an informal finance institutions where finite number of members contribute a fixed amount of money where the money polled is given to a member selected by lottery where by the process continues until all members get the chance. One all members get the chance the ikub may continue or not depending the interest of the members
} 